\title{
The application of principles of green building in traditional housing in Iraq
}

\begin{abstract}
Green building has become an important issue among architects and urban planners due to the increment in global warming risks and climatic changes which influenced negatively on natural resources. It is also one of measures been put forward to alleviate the significant impacts of the influence of buildings on the environment, society and economy. There have been extensive studies on green buildings, as evidenced in the rapid growing number of papers been published in last decades. These studies have been conducted in both developed countries and developing countries, indicating this is a global issue. However, there is lack of extensive researches on the green buildings in Iraq that is crucial for the future exerts. This paper reports the definition of green building, the environmental, social and economical aspects of green building, and application of green building's principles in traditional housing in Iraq.
\end{abstract}

Keyword: Green building; Traditional housing in Iraq; Courtyard 